\title{
INFLUENCING FACTORS OF FACIAL SPA TREATMENT ON VISIT INTENTION: AN IMPORTANCE-PERFORMANCE MATRIX ANALYSIS (IPMA) APPROACH
}

\author{
Sook-Fern Yeo \\ Multimedia University \\ Cheng-Ling Tan* \\ Universiti Sains Malaysia \\ Kah-Boon Lim \\ Multimedia University \\ Elaine Lam \\ Multimedia University
}

\begin{abstract}
Nowadays, grooming is considered an essential part of life to maintaining and up keeping a healthy and hygienic outlook which plays a key role in social bonding. As it turns out, the desire to looking good has spawned a wide range of beauty products causing the beauty industry to thrive and grow at a rapid rate. In other words the Malaysian Beauty Salon Markets have become big business today, driven by a rising population, disposable incomes, urbanisation and increasing influence of western culture to look good and to feel good. The beauty market is valued at USD 119.24 million and is expected to grow at a CAGR of 5.23\% in the next five years, to USD 153.86 million in 2015. As a result of a highly fragmented in this market, the need for differentiation from other salons is impendency for this industry. This research aims to study the different attributes of customer's concerns and reveals the final factors that generate customer intention to visit facial spa treatment centres in Malaysia. The effort is devoted to identifying those dimensions of services provided in facial spa treatment centres for instance, atmospheric, service quality, price, brand image and location which aid to build up a greater relationship with their patrons. Data is collected via questionnaires distribution from the target population of the female with the age range from 16-63 years old. A sample size of 308 was studied and data analysis involving Structural Equation Modeling SmartPLS version 3.0 software were used. Service quality reached the conclusion as the strongest predictor in influencing customer intention to visit facial spa treatment centres, followed by the factors of price and brand image. Further to that, an Importance-Performance matrix analysis was conducted in order to identify factors that need to be given priority for spa owners in Malaysia. These findings made contributions beyond the high context services for instance beauty salons, massage salons, hair salons, nail salons, financial consulting and medical care with the matching services characteristics.
\end{abstract}

Keywords: facial spa, price, service quality, brand image, atmospheric, visit intention; Malaysia

Received: 9 July 2019

Accepted: 11 September 2020

- Corresponding author: Graduate School of Business, Universiti Sains Malaysia, 11800 Pulau Pinang, Malaysia. Tel: +6046532789; E-mail: tanchengling@usm.my 


\section{INTRODUCTION}

Along with generalized human perception towards the importance of beauty, the urge to look better is not only exclusive to women now but also extends to men as well. In general, people think that beautiful people get a better life to compare to his/her less appealing counterparts for as the saying goes, "people do judge a book by its cover, however, a beautiful cover prompts a closer reading" (Lorenzo, Biesanz, \& Human, 2010). Humans have a common halo effect that physically attractive people are more likely to get promoted to a higher position and receive more pay (Young, 2011).

Today, a growing interest of self-grooming makes beauty care as a big business which contributes significantly to a national economy both in terms of revenue and employment generation. Facial spa treatment has marked an iconic image of gorgeousness and relaxation in Malaysian culture. With the era of increasing awareness of grooming and health consciousness, the role of facial spa treatment centres along with technology and hygiene level have been raised up. In the past decade, thousands of beauty salon market or beauticians career have sprung up all over the country (Akter, 2009).

Intelligence \& Partner (2016) indicated that, in 2015, Malaysian Beauty Salon Market valued at USD 119.24 million and is expected to grow at a CAGR of 5.23\% in the next five years to USD 153.86 million. Among these, skin care witnessed 32.73million beauty salon market revenue. The market will be majorly driven by the rise in population, disposable incomes, urbanisation and the increasing influence of western culture in Malaysia. Due to the necessity of the service, the market is believed to be steady in the near future. Maximum growth will be dominated by the cosmetic treatments, followed by skin care products and treatment even though hair care dominates the market segments. In term of services, the higher propensity of females to visit beauty salons continue to draw major revenues from the industry

However, to succeed in this fast-growing industry is not an easy task as there is a substantial number of players increasing in this market. Changes in the business environment are constant, which give rise to a critical need for these facial spa treatment centre to have own distinctive features and advantages. It has become a significant concern for research to investigate the group of clientele who are interested in beauty care services and their expectations towards it. This research attempts to identify the dimensions of factors on which the consumers give the most emphasis in deciding their revisit intention towards facial spa treatment.

Accordingly, understanding the concern factors of customers and satisfying them to maximize customer patronage is the top priority goal and significant part to strive for in the development of beauty care business. Efforts are made to measure customers' perceptions of service attributes and intention to patronage in order to raise the quality and value of offerings and customer services experience in the industry such as a hotel (Yeo, Stany Wee, Goh, Lam, Tan, \& Tan, 2012), homestay (Toh, Tan, \& Yeo, 2016) and packaging industry (Yeo, Tan, Lim, \& Khoo, 2020). This research aims at studying different attributes of the customers' preferences and reveals the final factors that generate customer intention to visit a facial spa treatment centre in Malaysia. 


\section{LITERATURE REVIEW}

\subsection{Visit Intention}

Consumer visit intention is amalgamation of normative beliefs, attitude and motivations that will impact buying behaviour. Visit intention is build up by the willingness to stay longer in store, convey positive word-of-mouth, purchase more in the future and repurchase. Choudhary (2016) defined visit intention with various forms. It has been reflected as intention of continuous shopping in the store, intention of showing preference to the store, intention of first choice consideration, intention of talking positive of the store, intention of recommend others who need advices and finally, intention of encourage others to patronage the store.

In the beauty care service context, the intention of visiting facial spa treatment centres could be inspected under the context of "purchase intention" as the consumers are purchasing an experience or services (Lau, 2015). In the study of Oosthuizen, Spowart, and De Meyer-Heydenrych (2015), purchase intention was determined through the level of customers' perceived value and perceived relative price. A competent value proposition that strikes a balance between perceived quality and the relative price is necessary to stimulate customers' buying intention (Retail-FMCG, 2012). Moreover, purchase intention was also influenced by the consumers' behaviour which decides how they act in the purchasing process in order to satisfy their perceived needs (Parumasur \& Lombard, 2015). Chaiyasoonthorn, Suksa-ngiam, and Distance (2011) indicated that the customers' total consumption could be greatly predicted by the purchase intention. Hence, managers were suggested to develop marketing strategies to enhance customers' purchase intention.

In study of spa context, understanding the demand factors that pushing spa guests on deciding a visit aids spa business to predict the future behaviour of customers and respond to the change of demand effectively (Toncev \& Podovac, 2016). Push-pull concept adopted in the study of Cheung (2012) as well, which suggested that spa patrons were actually not difficult to please as their visit intention were generally motivated intrinsically by a set of push factors such as relaxation, selfreward, health and beauty and they might justify themselves the decision to visit the spa was correct. Due to the limited knowledge in spa treatment techniques, spa guests tend to use the tangible cues to access the quality of the treatment services. A well-managed sensory environmental resources in the sight and touch aspect was vital in generating customer pleasure of emotion which had a direct influence on consumer visit intention. On the other hand, study of EL-refae (2012) elucidated that dimension of Tangibles and Empathy on service quality are significant in understanding customer satisfaction and behavioural intention on Malaysian Spa Centre.

\subsection{Atmospherics}

The review of the literature provides a comprehensive insight into atmospherics, which acts as the important environmental cues in intensifying the service environment, attracting consumers and creating specific emotional effects that enhance customers' consumption probability. These cues involve music, lighting, a bright and colourful environment which had shown significant influence on consumers' perception towards the overall service environment image, further evoking their psychological appeal and attracting patronage. Customers intend to visit the service environment which they perceived consistent with their personality (Adiele \& Justin. 2013). In order to differentiate in this competitive environment, business adopted atmospherics elements as a 
strategic input to generate the attractive power that enhances popularity and assure the future patronage which build up the customer visit intention (Choudhary, 2016). According to Liao, Huang, Huang, and Deeseentham (2012), background music allows customers indulge in joyful environment which impacted their perceived value with relaxed and comfortable sensorial. Correspondingly, Soh, Jayaraman, Choo and Kiumarsi (2015) found that background music tempo has an effect on consumers' pleasure and arousal. As a result, atmospherics cues were positively associated with purchase intention. The greater convenience of the environmental design, the higher purchase intention could be promoted Heung and $\mathrm{Gu}$ (2012) indicated that positive atmospherics elicits consumers' emotion and lead towards their favourable approach behaviour. Contrarily, the negative atmosphere results in avoidance behaviours that evoke dissatisfaction or desire to leave (Aina, Jalil, Fikry, \& Zainuddin, 2016). With these convincing literature, the first hypothesis is developed as:

\section{H1: There is a significant positive relationship between atmospherics and customer visit intention.}

\subsection{Service Quality}

Regarding to the field of service marketing, service quality is the most concerned issues of the researchers. Service quality is defined as the gap between customer expectations and perceptions toward the service delivered (Grönroos, 1984; Parasuraman, Zeithaml, \& Berry, 1991). Cronin and Taylor (1992) described service quality as an attitude generated by the personal's weightedevaluation toward the specific dimensions of service performance. Service quality is the individual's weighted-evaluation of the attitude towards the specific dimensions of service performance (Cronin and Taylor, 1992). According to Zeithaml and Bitner (2003), service quality is emphasized on the excellence or superiority of a service provider's performance which is arises from the judgement of consumers. Service quality has been researched in the healthcare industry with two dimensions of technical service quality and functional service quality (Yeo, Tan, \& Goh, 2018). Service personnel's friendliness and responsiveness have a positive influence on the overall consumers' evaluation of service quality. Service quality is one of the attributes that offer differentiation and arouse cusutomers' visit intention (Lien \& Kao, 2010). Besides that, Kwok, Jusoh and Khalifah (2017) suggested that the service provider are the key element that determines the perceived service quality among the customers. In addition, Hamenda (2018) stressed that service quality should be introduce in the organisation's strategic plan so that it can improve customers' satisfaction which later lead to loyalty. When service quality is evaluated positively, customers' behavioural intention shows a favourable disposition (Hou, Hu, \& Wei, 2013). Conversely, customers' behavioural intention presents an unfavourable side when service quality is perceived negatively. Hence, the second hypothesis tested in this study is:

\section{H2: There is a significant positive relationship between service quality and customer visit intention.}

\subsection{Brand Image}

Brand image is the symbolic characteristic of the products or services in the consumers' mental picture. It plays a crucial role for a customer in selecting and determining beauty care service providers (Khan \& Tabassum, 2012). However, Kotler and Armstrong (2018) defined brand image 
as a set of faiths that consumer held toward a specific brand. A valuable brand enables business to establish or enhance consumers' trust with their products or services (Lien, Wen, Huang, \& Wu, 2015). Besides, it was found that brand image has a positive significant relationship towards purchase intention through a celebrity endorser (Yeo, Lim, Goh, \& Tan, 2015). Customers show their preference when the brand image corresponds with their self-esteem (Jayesh \& Pradip, 2014). Brand image is the key driver of customer purchase intention and has a positive mediating effect through price and value (Lien et al., 2015) A positive brand image exceeds consumers' expectation, enhancing the organization's goodwill and brand value as well. It was defined as any "name, term, sign, symbol, and design" or combination of these that are extremely important for stimulating customer choice or visit intention (Ogwo \& Igwe, 2012). Thereby, the fourth hypothesis is described as follow:

\section{H3: There is a significant positive relationship between brand image and customer visit intention.}

\subsection{Price}

Price is the sum of money sacrificed in the process of acquiring products or services. It's an essential factor for affecting choices during the selection of vendors, services or brands (Pomering, Noble, \& Johnson, 2011). According to Pomering et al., (2011), price is the money charged for the product's consumption; it can influence demand and is therefore important in managing capacity use by helping to balance load and is also a key positioning factor, influencing how the product, or brand, is thought of by the consumer relative to the competition. Yaman, Alias, and Ishak (2012) demonstrated that a successful salon and spa business besides of providing superior services and treatments with quality products and a pleasurable atmosphere, understanding of pricing at an affordable range that better accommodate consumers' willingness to patronage on a regular basis is importance as well. Spa business adopt various pricing strategies for their services for example price bounding, special discount or special offer in order to retain the regular patrons while attract new customers (Kassim, Ahmad, Hassan, \& Mohd, 2016). Price perceptions contribute to perceived value and evoke customers' visit intention (Agwu and Carter, 2014). In the positive role, the price is perceived as quality or prestige (Huang and Sarigöllü, 2012). However, as a negative cue, the price is purely an economic sacrifice (Gordon, 2012). Therefore, the third hypothesis in this study is:

\section{H4: There is a significant positive relationship between price and customer visit intention.}

\subsection{Location}

Location is an important determinant of consumers in making store choice decisions. Location is perceived in terms of "time and distance that is a particularly compelling value proposition" while the physical access to a store and the key sacrifices a customer made while utilizing store based formats (Jere \& Jere, 2014). Most of the customers selecting their current salons based on the location (Khan \& Tabassum, 2012). Beauty salons are generally located nearby the neighbourhood, shopping malls, business buildings or some places that are accessible (Thongplean, 2012). The geographical location along with concentrated transport infrastructure allows patrons to reach their destination in a cheap and quick way (Toncev \& Podovac, 2016). Hence, a strategic location and 
easy parking facility increase accessibility for consumers and thereby attracts great numbers of patrons (Zehir, 2013). Studies of Narteh (2013) showed that convenient location plays a major role in motivating customers visit to the services. Customers might consider visiting the service at the area that proximate with their study or work place. Even though existence of competitors in that particular area, it might also a selection criteria as it indicated there have many consumers. Consequently, the fifth hypothesis is developed as follow:

\section{H5: There is a significant positive relationship between location and customer visit intention.}

\section{METHODOLOGY}

Based on the literature review, the following research framework shown in Fig. 1 is developed.

Figure 1: Conceptual Framework

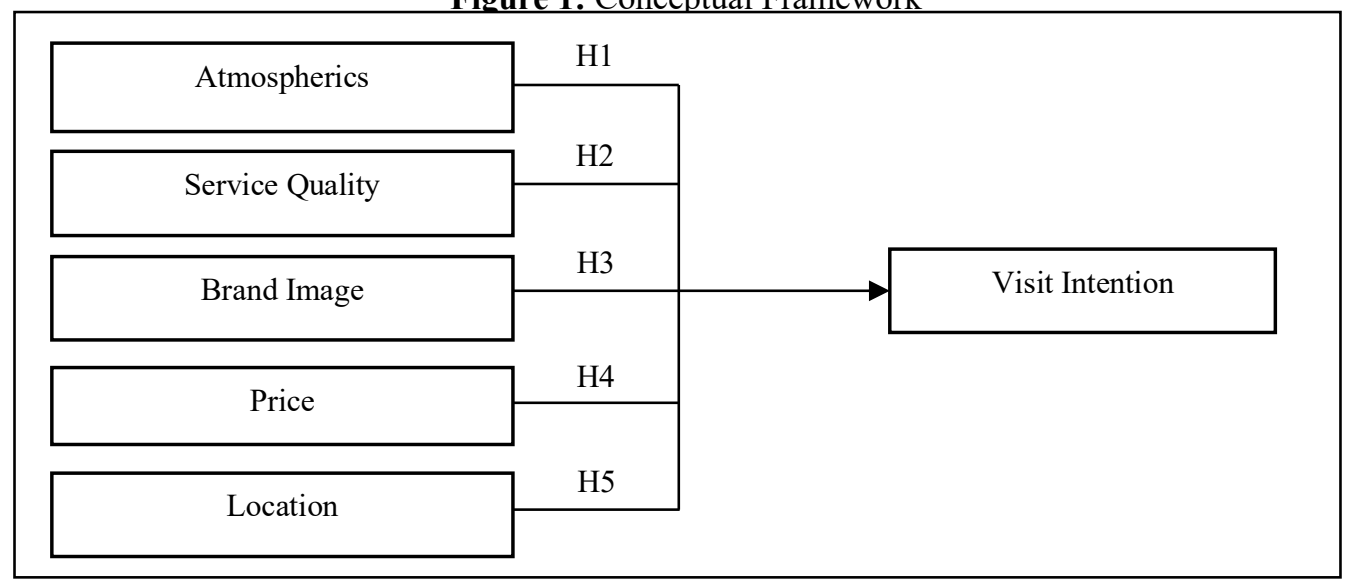

This study proposed a quantitative research design for data collection. The sample of customers were selected based on purposive sampling. The unit analysis for this study consists of customers who have visited the spa centre in Malaysia (e.g., Melaka, Johor Bahru and Kuala Lumpur). This is a cross-sectional study and data were collected at one point in time prior to approval from spa owners. Based on the $\mathrm{G}^{*}$ Power 3 analysis with the effect size of 0.15 at the significance level of $5 \%$ and statistical power level of $95 \%$ (Cohen, 1988) was run to determine the minimum required sample size. According to the analysis, the minimum sample size required is 138 . Nevertheless, a total of 350 questionnaires were distributed from September 2017 to December 2017 to the targeted respondents in Melaka, Johor Bahru and Kuala Lumpur. All the five variables in this study were measured using a 5-point Likert scale ranging from (1) strongly disagree to (5) strongly agree. Total 37 validated measurement items were adopted and adapted from previous studies (Ajzen \& Fischbein, 1980; Churchill \& Surprenant, 1982; Kotler, 1973; McCarthy, 1960). All the hypotheses were tested using Partial Least Squares (PLS) version 3.2.9. The PLS-SEM technique enables researchers to incorporate unobservable variables measured by indicators. 


\section{RESULTS AND DISCUSSION}

A total of 350 questionnaires were distributed to the targeted respondents. After the stipulated period, a total of 308 questionnaires were returned which yield a response rate of 88 percent. Respondents on this study are dominated by female, with the highest proportion of age level between 16 and 21 years old. The occupation distribution reveals that most of the respondents are students, which explain the majority of income level below RM1000. Additionally, respondents without visit experiences of Facial Spa Treatment Centre are higher than those who have visited before. Majority of them would visit facial spa treatments whenever they wish.

The measurement model was assessed to confirm the validity and reliability of the measurement items. The evaluation includes assessing the factor loadings, composite reliability (CR), and average variance extracted (AVE) to confirm the convergent validity (Hair, Ringle, \& Sarstedt, 2013). As shown in Table 1, all factor loadings are meeting the minimum requirements.

Table 1: Measurement model

\begin{tabular}{|c|c|c|c|c|}
\hline Constructs & Question Items & Loadings & AVE & CR \\
\hline \multirow[t]{6}{*}{ Atmospherics } & $\mathrm{A} 1$ & 0.717 & 0.555 & 0.882 \\
\hline & $\mathrm{A} 2$ & 0.726 & & \\
\hline & A3 & 0.792 & & \\
\hline & A4 & 0.703 & & \\
\hline & A5 & 0.775 & & \\
\hline & A6 & 0.751 & & \\
\hline \multirow[t]{10}{*}{ Brand Image } & B1 & 0.736 & 0.573 & 0.930 \\
\hline & B2 & 0.793 & & \\
\hline & B3 & 0.779 & & \\
\hline & B4 & 0.816 & & \\
\hline & B5 & 0.788 & & \\
\hline & B6 & 0.752 & & \\
\hline & B7 & 0.607 & & \\
\hline & B8 & 0.741 & & \\
\hline & B9 & 0.773 & & \\
\hline & $\mathrm{B} 10$ & 0.768 & & \\
\hline \multirow{10}{*}{ Service Quality } & S1 & 0.721 & 0.511 & 0.912 \\
\hline & S2 & 0.705 & & \\
\hline & S3 & 0.769 & & \\
\hline & S4 & 0.738 & & \\
\hline & S5 & 0.736 & & \\
\hline & S6 & 0.661 & & \\
\hline & S7 & 0.749 & & \\
\hline & S8 & 0.743 & & \\
\hline & S9 & 0.709 & & \\
\hline & $\mathrm{S} 10$ & 0.608 & & \\
\hline \multirow[t]{3}{*}{ Location } & L1 & 0.761 & 0.629 & 0.836 \\
\hline & L2 & 0.810 & & \\
\hline & L3 & 0.809 & & \\
\hline \multirow[t]{2}{*}{ Price } & P1 & 0.690 & 0.611 & 0.862 \\
\hline & $\mathrm{P} 2$ & 0.809 & & \\
\hline
\end{tabular}




\begin{tabular}{lllll}
\hline & P3 & 0.804 & & \\
& P4 & 0.816 & & 0.857 \\
\hline Visit Intention & V1 & 0.770 & 0.667 & \\
& V2 & 0.862 & & \\
V3 & 0.815 & & \\
\hline \hline
\end{tabular}

Figure 2: Measurement model

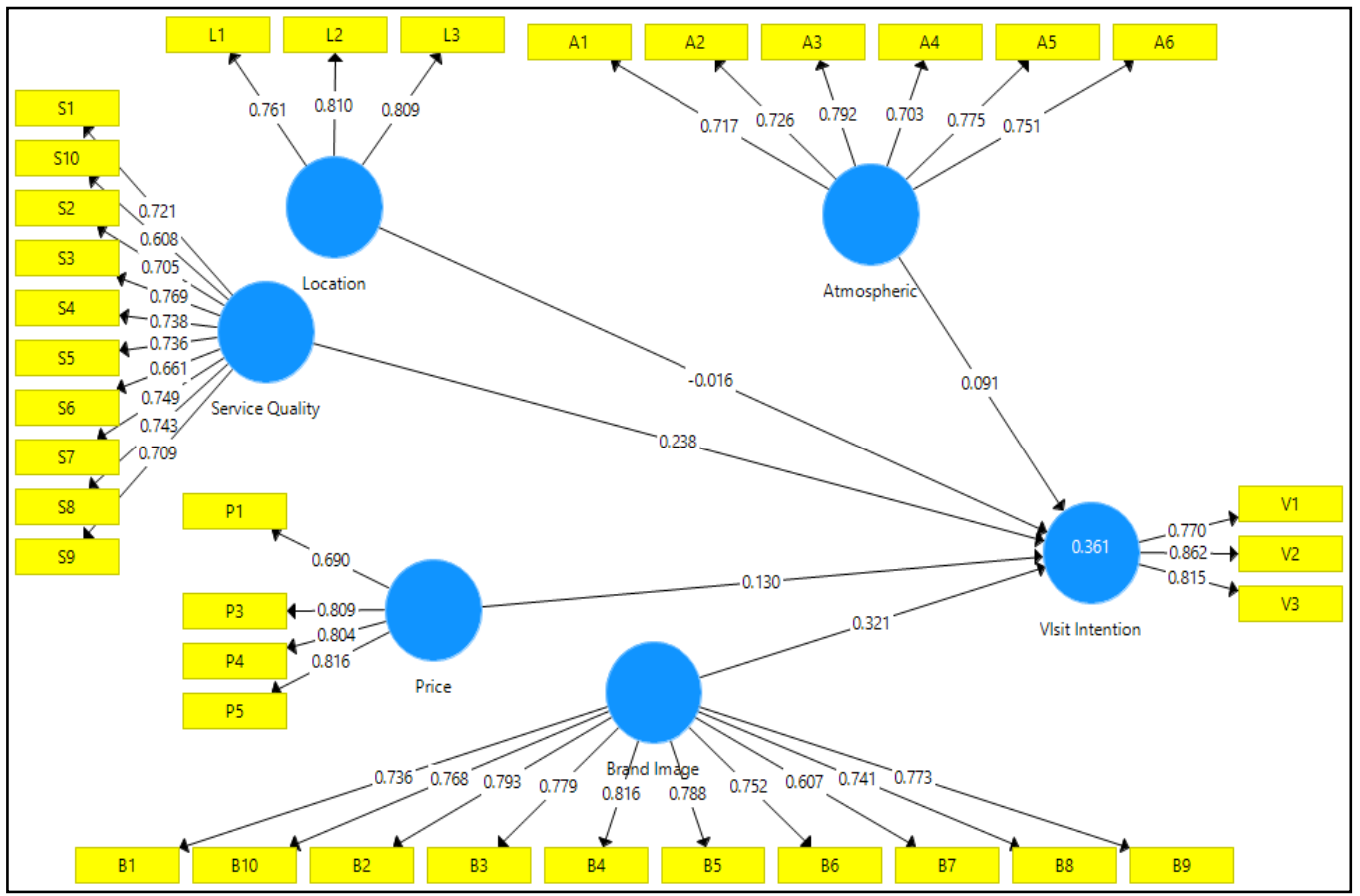

The square root of the AVE value for each construct has exceeded its correlation with other constructs. This indicates that our model is sufficient to support for discriminant validity at the construct level (Fornell \& Larcker, 1981). The loading and cross-loadings for the measurement model for this study are shown in Table 2. All items showed high loaded in relation to their respective constructs and low in relation to other constructs. According to Chin (1998), this results in sufficient support regarding convergent validity at the item levels.

Table 2: Loadings and cross-loadings for the measurement model

\begin{tabular}{lcccccc}
\hline \hline & Atmospheric & Brand Image & Location & Price & Service Quality & Visit Intention \\
\hline A1 & $\mathbf{0 . 7 1 7}$ & 0.312 & 0.191 & 0.172 & 0.511 & 0.276 \\
A2 & $\mathbf{0 . 7 2 6}$ & 0.345 & 0.275 & 0.190 & 0.448 & 0.277 \\
A3 & $\mathbf{0 . 7 9 2}$ & 0.386 & 0.227 & 0.240 & 0.489 & 0.336 \\
A4 & $\mathbf{0 . 7 0 3}$ & 0.337 & 0.312 & 0.174 & 0.457 & 0.320 \\
A5 & $\mathbf{0 . 7 7 5}$ & 0.350 & 0.285 & 0.208 & 0.556 & 0.327 \\
A6 & $\mathbf{0 . 7 5 1}$ & 0.409 & 0.314 & 0.172 & 0.495 & 0.371 \\
\hline
\end{tabular}




\begin{tabular}{lcccccc}
\hline \hline & Atmospheric & Brand Image & Location & Price & Service Quality & Visit Intention \\
\hline B1 & 0.361 & $\mathbf{0 . 7 3 6}$ & 0.320 & 0.129 & 0.473 & 0.411 \\
B10 & 0.439 & $\mathbf{0 . 7 6 8}$ & 0.305 & 0.187 & 0.481 & 0.417 \\
B2 & 0.367 & $\mathbf{0 . 7 9 3}$ & 0.338 & 0.172 & 0.416 & 0.389 \\
B3 & 0.365 & $\mathbf{0 . 7 7 9}$ & 0.268 & 0.128 & 0.411 & 0.401 \\
B4 & 0.346 & $\mathbf{0 . 8 1 6}$ & 0.345 & 0.150 & 0.429 & 0.387 \\
B5 & 0.361 & $\mathbf{0 . 7 8 8}$ & 0.329 & 0.183 & 0.432 & 0.376 \\
B6 & 0.360 & $\mathbf{0 . 7 5 2}$ & 0.288 & 0.187 & 0.472 & 0.451 \\
B7 & 0.221 & $\mathbf{0 . 6 0 7}$ & 0.277 & 0.151 & 0.282 & 0.287 \\
B8 & 0.383 & $\mathbf{0 . 7 4 1}$ & 0.267 & 0.147 & 0.433 & 0.403 \\
B9 & 0.405 & $\mathbf{0 . 7 7 3}$ & 0.290 & 0.249 & 0.505 & 0.418 \\
L1 & 0.272 & 0.339 & $\mathbf{0 . 7 6 1}$ & 0.153 & 0.327 & 0.184 \\
L2 & 0.212 & 0.273 & $\mathbf{0 . 8 1 0}$ & 0.112 & 0.269 & 0.213 \\
L3 & 0.368 & 0.340 & $\mathbf{0 . 8 0 9}$ & 0.192 & 0.378 & 0.235 \\
P1 & 0.155 & 0.116 & 0.132 & $\mathbf{0 . 6 9 0}$ & 0.169 & 0.228 \\
P3 & 0.242 & 0.194 & 0.151 & $\mathbf{0 . 8 0 9}$ & 0.213 & 0.201 \\
P4 & 0.213 & 0.174 & 0.110 & $\mathbf{0 . 8 0 4}$ & 0.210 & 0.234 \\
P5 & 0.200 & 0.216 & 0.213 & $\mathbf{0 . 8 1 6}$ & 0.202 & 0.214 \\
S1 & 0.538 & 0.396 & 0.268 & 0.129 & $\mathbf{0 . 7 2 1}$ & 0.356 \\
S10 & 0.400 & 0.359 & 0.269 & 0.187 & $\mathbf{0 . 6 0 8}$ & 0.289 \\
S2 & 0.527 & 0.399 & 0.256 & 0.112 & $\mathbf{0 . 7 0 5}$ & 0.379 \\
S3 & 0.531 & 0.442 & 0.292 & 0.233 & $\mathbf{0 . 7 6 9}$ & 0.450 \\
S4 & 0.505 & 0.396 & 0.305 & 0.223 & $\mathbf{0 . 7 3 8}$ & 0.372 \\
S5 & 0.508 & 0.441 & 0.295 & 0.129 & $\mathbf{0 . 7 3 6}$ & 0.302 \\
S6 & 0.375 & 0.385 & 0.353 & 0.176 & $\mathbf{0 . 6 6 1}$ & 0.361 \\
S7 & 0.474 & 0.442 & 0.348 & 0.175 & $\mathbf{0 . 7 4 9}$ & 0.386 \\
S8 & 0.432 & 0.448 & 0.260 & 0.260 & $\mathbf{0 . 7 4 3}$ & 0.352 \\
S9 & 0.426 & 0.428 & 0.287 & 0.184 & $\mathbf{0 . 7 0 9}$ & 0.361 \\
V1 & 0.324 & 0.422 & 0.175 & 0.185 & 0.364 & $\mathbf{0 . 7 7 0}$ \\
V2 & 0.421 & 0.457 & 0.209 & 0.239 & 0.455 & $\mathbf{0 . 8 6 2}$ \\
V3 & 0.304 & 0.406 & 0.271 & 0.265 & 0.426 & $\mathbf{0 . 8 1 5}$ \\
\hline & & & & & & \\
\end{tabular}

Based on Hair et al., (2013), the statistical significance of the path coefficients of the structural model was then determined by using the bootstrap procedure with 5000 resamples. Table 3 shows the direct relationship of brand image $(\beta=0.321, \mathrm{p}<0.01)$, price $(\beta=0.130, \mathrm{p}<0.01)$ and service quality $((\beta=0.238, \mathrm{p}<0.01)$ have significant positive relationship with customer visit intention whereas atmospheric $(\beta=0.072)$ and location $(\beta=-0.016)$ were found to have no significant relationship with customer visit intention.

Table 3: Results of the hypothesis testing

\begin{tabular}{cccccccc}
\hline \hline Hypothesis & Path & $\begin{array}{c}\text { Beta } \\
\text { Value }\end{array}$ & $\begin{array}{c}\text { Standard } \\
\text { Error } \\
\text { (STERR) }\end{array}$ & t - Value & $\mathbf{2 . 5 \%}$ & $\mathbf{9 7 . 5 \%}$ & Decision \\
\hline H1 & $\begin{array}{c}\text { Atmosphe } \\
\text { ric }-> \\
\text { Visit } \\
\text { Intention } \\
\text { Brand }\end{array}$ & 0.091 & 0.072 & 1.275 & -0.046 & 0.218 & $\begin{array}{c}\text { Not } \\
\text { supported }\end{array}$ \\
& 0.321 & 0.067 & $4.769 * *$ & 0.181 & 0.446 & Supported \\
Image -> & & & & & &
\end{tabular}




\begin{tabular}{|c|c|c|c|c|c|c|c|}
\hline Hypothesis & Path & $\begin{array}{l}\text { Beta } \\
\text { Value }\end{array}$ & $\begin{array}{l}\text { Standard } \\
\text { Error } \\
\text { (STERR) }\end{array}$ & $t$ - Value & $2.5 \%$ & $97.5 \%$ & Decision \\
\hline & $\begin{array}{c}\text { Visit } \\
\text { Intention }\end{array}$ & & & & & & \\
\hline H3 & $\begin{array}{l}\text { Location } \\
\text {-> Visit } \\
\text { Intention }\end{array}$ & -0.016 & 0.052 & 0.312 & -0.126 & 0.077 & $\begin{array}{c}\text { Not } \\
\text { supported }\end{array}$ \\
\hline H4 & $\begin{array}{c}\text { Price -> } \\
\text { Visit }\end{array}$ & 0.130 & 0.052 & $2.508 * *$ & 0.024 & 0.237 & Supported \\
\hline H5 & $\begin{array}{c}\text { Intention } \\
\text { Service } \\
\text { Quality -> } \\
\text { Visit } \\
\text { Intention }\end{array}$ & 0.238 & 0.083 & $2.849 * *$ & 0.063 & 0.387 & Supported \\
\hline
\end{tabular}

$* * \mathrm{p}<0.01,{ }^{*} \mathrm{p}<0.05$, Bootstrapping $(\mathrm{n}=5000)$

The Importance-Performance Matrix Analysis (IPMA) has been performed in this study. Variables with high importance and low performance can be easily identified by assessing IPMA (Hock, Ringle, \& Sarstedt, 2010). Correspondingly, the outcomes from IPMA analysis will contribute to insights for company's owners to overcome and improve on identified areas with low performance and high importance (Schloderer, Sarstedt, \& Ringle, 2014). The importance value is the direct effect of an exogenous variable on an endogenous variable, whereas the performance value is the latent variable score on a scale from 0 to 100 .

Table 4: Importance-performance matrix analysis (IPMA) results

\begin{tabular}{lcc}
\hline \hline \multicolumn{1}{c}{ Latent variable } & $\begin{array}{c}\text { Visit Intention } \\
\text { (importance) }\end{array}$ & $\begin{array}{c}\text { Index value } \\
\text { (performance) }\end{array}$ \\
\hline Atmospheric & 0.107 & 63.658 \\
Brand Image & 0.373 & 60.501 \\
Location & -0.017 & 57.525 \\
Price & 0.122 & 52.791 \\
Service Quality & 0.283 & 60.129 \\
\hline \hline
\end{tabular}

Figure 3 shows the IPMA map, atmospherics has the highest performances but it was the second lowest least important factor. Besides, the IPMA map also shows that brand image is equally an important factor for customers' visit intention to the facial spa centre in Malaysia. Location, on the other hand, has little relevance because it is of low importance even though it has a relatively high performance compared to price. This has indicated that location has no contribution to overall customers' intention to visit facial spa centres. Furthermore, brand image has the second highest performance and highest in terms of importance towards customers' visit intention to the facial spa centre. In terms of customers' visit intention to the facial spa centre in Malaysia, the results from IPMA analysis show that atmospherics as well as brand image have a greater impact. 
Figure 3: IPMA for visit intention

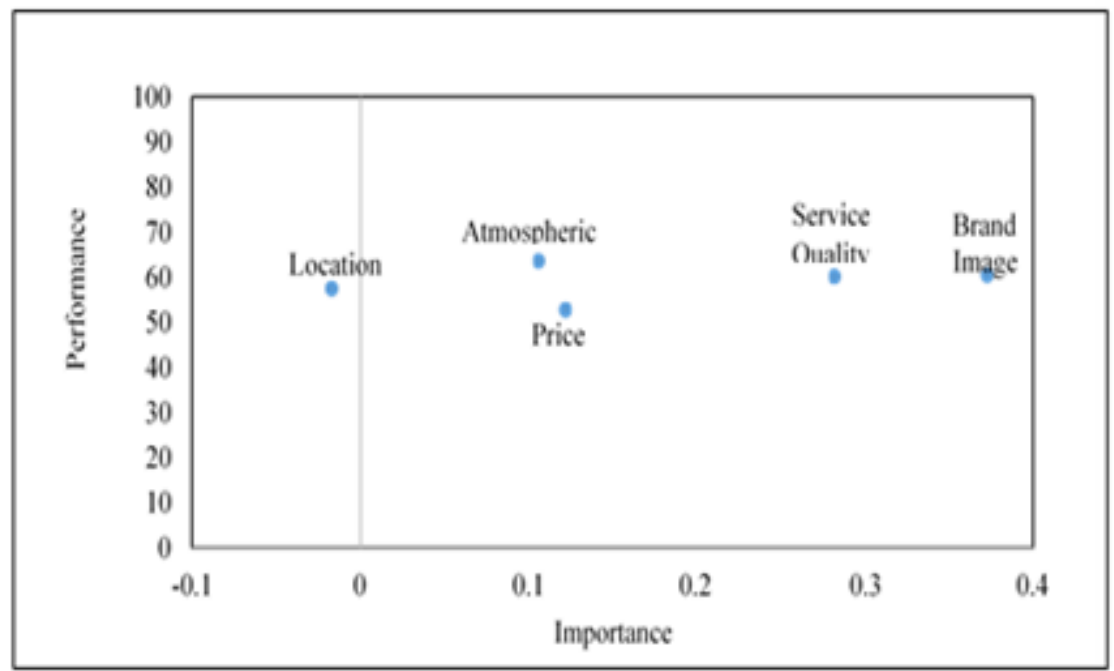

\section{CONCLUSION}

Service quality has been raised up as the most influential factor in determining customers' visit intention. Since facial spa treatment is a high customer contact service, literature emphasized on the performance of service provider as a cue on evaluating service quality. Hence, training and professional development are crucial for the service industry to maintain a high service quality. Another finding concluded that price is an important determinant of customers' visit intention. Business should convey the value of their service in order to show the customers the worthiness and value of their prices. Price indicates the value including quality and benefits that customers sacrifice in exchange for it, thus while customers perceived the value of the price, they will have the intention to visit the service. The final finding is the positive influence of brand image on customers' visit intention. As the brand image instils trust of a brand, customers prefer to visit the service with the strong brand image to reduce the risk of purchase. Therefore, it is imperative for a business to develop a strong brand image with the participation of community building programs or employment of brand ambassador. Future research could cover on other variables such as customer satisfaction and customers' revisit intention to gain valuable insights into the beauty care service industry in Malaysia. Besides that, in future, this study could be expanded on a national basis to discover the underlying factors that induce customers' intention to visit facial spa treatment centres with the cross-cultural dimensions in mind, which provides the guidance to the industry on taking strategic decisions for business expansion.

\section{REFERENCES}

Adiele, K C., \& Justin, M. O. G. (2013). Customer relationship management and bank performance in Nigeria: an empirical validation study. International Journal of Science. 2(1), 416-422. 
Aina, N., Jalil, A., Fikry, A., \& Zainuddin, A. (2016). The impact of store atmospherics, perceived value, and customer satisfaction on behavioural intention. Procedia Economics and Finance, 37(16), 538-544.

Agwu, M.E., \& Carter, A.L. (2014). Mobile phone banking in Nigeria: benefits, problems and prospects. International Journal of Business and Commerce, 3(6), 50-70.

Akter, S. (2009, February 17). Personal gets revenue glamour: earnings rise to talk. The Daily Star. Retrieved from https://www.thedailystar.net/news-detail-76232

Chaiyasoonthorn, W., Suksa-ngiam, W., \& Distance, A. (2011). Factors influencing store patronage: a study of modern retailers in Bangkok, Thailand. International Journal Trade Economy Finance, 2, 520-525.

Cheung, B. C. M. (2012). A study of the interrelationship of spa guests' motivations, perceived service quality, value, satisfaction and behavioral intentions (Unpublished doctoral dissertation). Oklahoma State University, Oklahoma.

Chin, W. W. (1998). The partial least squares approach to structural equation modeling. In G. Marcoulides (Ed.), Modern Methods for Business Research (pp.295-336), Mahwah, NJ: Lawrence Erlbaum Associates.

Choudhary, F. S. (2016). Store Atmospherics Affects Patronage Intentions - A Conceptual Framework. International Journal of Science Technology and Management, 5(3), 188-198.

Cronin, J. J., \& Taylor, S. A. (1992). Measuring service quality: A re-examination and extension. Journal of Marketing, 56, 55-68.

EL-refae, B. A. A. (2012). The relationships between service quality, satisfaction, and behavioural intentions of Malaysian spa center customers. International Journal of Business and Social Science, 3(1), 198-206.

Fornell, C., \& Larcker, D. F. (1981). Evaluating structural equation models with unobservable variables and measurement error. Journal of Marketing Research, 18(1), 39-50.

Gordon, R. (2012). Re-thinking and re-tooling the social marketing mix. Australasian Marketing Journal, 20(2), 122-126.

Grönroos, C. (1984). A service quality model and its marketing implications. European Journal of Marketing, 18(4), 36-44.

Hair, J. F., Ringle, C. M., \& Sarstedt, M. (2013). Partial Least Squares Structural Equation Modeling: rigorous applications, better results and higher acceptance. Long Range Planning, $46(1-2), 1-12$.

Hamenda, A. (2018). An integrated model of service quality, price fairness, ethical practice and customer perceived values for customer satisfaction of sharing economy platform. International Journal of Business and Society, 19(3), 709-724.

Heung, V. C. S., \& Gu, T. (2012). Influence of restaurant atmospherics on patron satisfaction and behavioural intentions. International Journal of Hospitality Management, 31(4), 11671177.

Hock, C., Ringle, C. M., \& Sarstedt, M. (2010). Management of multi-purpose stadiums: importance and performance measurement of service interfaces. International Journal Services Technology and Management, 14(2), 188-207.

Hou, M., Hu, Z., \& Wei, S. (2013). Personnel service quality and patronage intention moderation analysis of consumption emotion. International SAMANM Journal of Marketing and Management, 1(2), 41-55.

Huang, R., \& Sarigöllü, E. (2012). How brand awareness relates to market outcome, brand equity, and the marketing mix. Journal of Business Research, 65(1), 92-99. 
Jayesh, S. S., \& Pradip, M. (2014). To study the perception of women as customers towards beauty service in Western Mumbai, International Journal of Scientific Research and Reviews, 3(4), 52-64.

Kassim, A., Ahmad, A., Hassan, S. R., \& Mohd, N. (2016, May 13-16). Customer Satisfactions and Customer Loyalty in Spa Industry: Cases from Muslimah SPA Concept, Shah Alam, Malaysia, Paper Presented at the 14th APacCHRIE Conference: Crisis Management and Business Continuity in the Tourism Industry, Bangkok, Thailand.

Khan, P. I., \& Tabassum, A. (2012). Beautification for male in Dhaka: exploring the customer groups, services and selection of service providers. World Review of Business Research, 2(4), 71-85.

Kotler, P., \& Armstrong, G. (2018). Principles of Marketing (17th ed.). Upper Saddle River, New Jersey: Pearson Education, Inc.

Kwok, S., Jusoh, A., \& Khalifah, Z. (2017). The mediating effects of value on service qualitysatisfaction relationship in Malaysian tourism industry. International Journal of Business and Society, 18(2), 363-372.

Liao, C. S., Huang, C. W., Huang, T. Y., \& Deeseentham, K. (2012). A cross-cultural examination of store environment cues and purchase intention in Taiwan and the United States. Journal of Applied Business and Economics, 13(1), 73-83.

Lien, N. H., \& Kao, S. (2010). The effects of service quality dimensions on customer satisfaction across different services types: alternatives differentiation as a moderator. Journal of Advances in Customers Research, 35, 522 -527.

Lien, C. H., Wen, M. J., Huang, L. C., \& Wu, K. L. (2015). Online hotel booking: the effects of brand image, price, trust and value on purchase intentions. Asia Pacific Management Review, 20(4), 210-218.

Lorenzo, G.L., Biesanz, J.C., \& Human, L.J. (2010). What is beautiful is good and more accurately understood: physical attractiveness and accuracy in first impressions of personality. Psychological Science, 21, 1777-1782.

Narteh, B. (2013). SME bank selection and patronage behaviour in the Ghanaian banking industry. Management Research Review, 36(11), 1061-1080.

Ogwo, E. O., \& Igwe, S. R. (2012). Some key factors influencing attitudes to patronage of gsm services: the Nigerian experience. International Journal of Business and Management, 7(18), 82-91.

Oosthuizen, M. D., Spowart, J., \& De Meyer-Heydenrych, C. F. (2015). The relationship between perceived price and consumers' purchase intentions of private label wine brands. African Journal of Hospitality, Tourism and Leisure, 4(42), 1-17.

Parasuraman, A., Valarie A. Zeithaml, \& Leonard L. Berry. (1991). Refinement and reassessment of the SERVQUAL scale. Journal of Retailing, 64, 12-40.

Parumasur, S.B. \& Roberts-Lombard, M. (2015). Consumer Behaviour (2nd ed.). Cape Town: Juta \& Company Ltd.

Pomering, A., Noble, G., \& Johnson, L. W. (2011). Conceptualising a contemporary marketing mix for sustainable tourism. Journal of Sustainable Tourism, 19(8), 953-969.

Retail-FMCG. (2012). Industry news. Retrieved from http://www.retail-fmcg.co.za/industry_news. htmPrivate_Label_South_Africa_2012

Schloderer, M. P., Sarstedt, M., \& Ringle, C. M. (2014). The relevance of reputation in the nonprofit sector: the moderating effect of socio-demographic characteristics. International Journal of Nonprofit and Voluntary Sector Marketing, 19(2), 110-126. 
Soh, K. L., Jayaraman, K., Choo, L. P., \& Kiumarsi, S. (2015). The impact of background music on the duration of consumer stay at stores: an empirical study in Malaysia. International Journal of Business and Society, 16(2), 247-260.

Thongplean, P. (2012). Service marketing mix factors affecting customers' decision on choosing a beauty salon (Unpublished master's dissertation), Srinakarinwirot University, Thailand.

Toh, T. J. S., Tan, C. L., \& Yeo, S. F. (2016). What are the attractiveness aspects that influence customer loyalty to homestays? A study in Taiwan. Jurnal Pengurusan, 48, 201-218.

Tonĉev, M. J., \& Podovac, M. (2016, June 2-4). A survey on factors influencing tourists' decision to visit spa destination. 1st International Scientific Conference: Tourism in Function of Development of the Republic of Serbia. Vrnjaţka Banja, Serbia. Retrieved from http://www.tisc.rs/proceedings/index.php/hitmc/article/view/212/208

Yaman, R., Alias, Z., \& Ishak, N. M. (2012). Beauty treatment and spa design from Islamic perspective. Procedia - Social and Behavioral Sciences, 50, 492-501.

Yeo, S. F., Lim, K. B., Goh, M. L., \& Tan, S. H. (2015). The effect of celebrity endorser towards customer purchase intention. Advanced Science Letter, 21(6), 2164-2169.

Yeo, S. F., Tan, C. L., \& Goh, Y. N. (2018). Managing service quality, emotions and experience in healthcare industry: a proposed framework. International Conference on Management, Leadership and Governance ICMLG, Bangkok, Thailand (pp. 333-339).

Yeo, S. F., Tan, C. L., Lim, K. B., \& Khoo, Y. H. (2020). Product packaging: impact on customers' purchase intention. International Journal of Business and Society, 21(2), 857-864.

Yeo, S. F., Stany Wee, L. F., Goh, M. L., Lam, M. S., Tan, S. H., \& Tan, A. C. (2012, September 3-5). Customer satisfaction towards service quality in the hotel industry in Melaka. In Zainal, A., Radzi, S. M., Hashim, R., Chik, C. T. \& Abu, R. (Ed.) Current Issues in Hospitality and Tourism: Research and Innovations, Proceedings of the International Hospitality and Tourism Conference, IHTC (pp.81-85). Kuala Lumpur, Malaysia.

Young, P. (2011, March 12). Facial Physical Attractiveness, Its Importance and How It Is Part of Our DNA. ArticlesBase.com. Retrieved from http://www.articlesbase.com/beautyarticles/facial-physical-attractiveness-its-importance-and-how-it-ispart-of-our-dna-byphilipyoungmd-4377637.html

Zeithaml, V. A., \& Bitner, M. J. (2003). Services marketing: integrating customer focus across the firm. New York: McGraw-Hill. 